\title{
DEVELOPMENT OF TOURISM IN CENTRAL ASIA (ON THE EXAMPLE OF UZBEKISTAN AND KAZAKHSTAN)
}

\author{
Atadjanova Sayyora Melisovna \\ Candidate of historical sciences (PhD), Assistant-professor of National University of Uzbekistan \\ named after Mirzo Ulugbek, Tashkent, Republic of Uzbekistan
}

Article DOI: https://doi.org/10.36713/epra3292

\begin{abstract}
The article reveals the relevance of cooperation of Central Asia in the field of tourism during the years of independence, using the example of the Uzbek and Kazakh peoples. The rich historical, cultural and spiritual heritage of the Central Asian people, which has accumulated from ancient times to the present day. An interchange that can be traced back to the ancient Great Silk Road, which contributed to the enrichment of nationalities' cultures, the establishment of diplomatic relations between states, the establishment and development of trade relations and the spiritual enrichment of peoples. And nowadays the invaluable heritage of the Central Asian peoples contributes to the establishment and development of a new industry - tourism in the period of independence, as historical, sanitary, sports, gastronomic as well.
\end{abstract}

KEY WORDS: Tourism, culture, cooperation, World Tourism Organization, Tourism Fair Agreement.

\section{INTRODUCTION}

A significant event in the development of the tourism industry in Uzbekistan is the event that, on the basis of giving the government great attention to the formation and development of tourism potential in the republic, in 1993 the National Company "Uzbektourism" was accepted as a full member of the World Tourism Organization [1, p.23]. This provided great opportunities for establishing close contacts with travel agencies in many countries of the world, and to raise their interaction to a qualitatively new level. At the same time, Uzbekistan, like many other countries of the world, has become a regular participant in the International Tourism Fair (ITB) annually organized by the World Tourism Organization. So, having created the necessary tourism infrastructure in the country and entering the orbit of international tourism, Uzbekistan began to implement a wide network of cooperation with travel companies and firms of foreign countries. At the same time, close cooperation between the Tourism Industry of Uzbekistan, carried out with the countries of Central Asia, and in particular with Kazakhstan, is no exception.

\section{RESEARCH METHODS}

It is noteworthy that the Central Asian region is distinguished by its uniqueness, both in geographical location with contrasting natural and climatic features, its flora and fauna, as well as unique historical and cultural monuments of antiquity and modern achievements of the socio-economic, cultural and spiritual life of peoples. In this regard, over the years of independence between the republics of Central Asia at a qualitatively new level, an active connection has been established in the field of tourism, which makes it possible to maintain and further develop the close interaction that existed over the centuries between their peoples. This form of interaction and cultural and spiritual mutual enrichment of the peoples of Central Asia is most clearly manifested between the republics of Uzbekistan, Kazakhstan, Kyrgyzstan, Tajikistan, and Turkmenistan.

\section{RESULTS AND DISCUSSIONS}

International tourism continues to show steady and unremitting growth that exceeds the growth rate of the global economy and does not show 


\section{SJIF Impact Factor: 6.260| ISI I.F.Value:1.241| Journal DOI: 10.36713/epra2016 ISSN: 2455-7838(Online) EPRA International Journal of Research and Development (IJRD)}

any significant signs of weakening, given that global arrivals are expected to grow by $3.3 \%$ from 2010 to 2030 , and will reach 1.8 billion by 2030 , according to the UNWTO long-term forecast report Tourism on the way to 2030. Between 2010 and 2030, tourist arrivals in developing countries $(+4.4 \%$ per year) are expected to grow at a double rate compared to develop and the economy $(+2.2 \%$ per year). With the exception of Afghanistan, the Chinese Autonomous Region of Inner Mongolia and the Xinjiang Uighur Autonomous Region, and Turkmenistan, the total volume of international tourist arrivals in the CAREC region in 2018 is estimated by the World Tourism and Travel Council (WTTC) to be just under 20 million, with a growth forecast in the ten years to 2028, almost 5\%. Despite this, the aggregate share of CAREC countries (excluding the People's Republic of China) considered in a global context is less than $2 \%$ of world tourism. The market share owned by developing countries increased from $30 \%$ in 1980 to $45 \%$ in 2016 , and is expected to reach $57 \%$, or more than 1 billion tourist arrivals by 2030 [2, p.5-6].

Attaching great importance to the development of tourist relations between the republics of Central Asia, the leadership of Uzbekistan initiated the need to form its legislative base. This initiative found mutual support from the government of Kazakhstan and Kyrgyzstan. As a result of a unified approach and views on the development and strengthening of tourist relations, in January 1994, an Agreement was signed between representatives of the governments of the Republic of Uzbekistan and the Republic of Kazakhstan [3, p.17]. It provided for a wide range of cultural and spiritual interaction between the peoples of the two countries, including the deepening of cooperation in the fields of culture, health, science, education, tourism and sports. A similar document was also signed in January 1994 between the governments of the Republics of Uzbekistan and Kyrgyzstan [3, p.21].

In addition, based on the high interest of the parties in the development of mutually beneficial cooperation in the field of tourism, in December 1997, an agreement was signed in the city of Tashkent between the Government of the Republic of Kazakhstan, the Government of the Kyrgyz Republic and the Government of the Republic of Uzbekistan on cooperation in the field of tourism [4, p.33].

In order to further deepen and expand tourism cooperation, as well as to intensify this area, additional services, in June 8, 2000, another Agreement was signed in Astana. It was achieved between the governments of the Republic of Kazakhstan, the Kyrgyz Republic, the Republic of Tajikistan and the Republic of Uzbekistan, which focused on cooperation in the development of sanatorium, resort, health and tourist institutions and organizations for a period of 5 years [5, p.27]. The peculiarity of this Agreement was that it laid the foundation for the expansion of cooperation in the development of sanatorium, resort, health and tourism institutions and organizations in order to create the most favorable conditions in them for strengthening the health of citizens of their states, a deeper acquaintance with the culture, nature and attractions, as well as with historical monuments and national traditions of the peoples of neighboring countries. In addition, this document encouraged organizations to create joint ventures and to implement investment projects in the field of organizing spa treatment, rehabilitation and recreation for citizens.

According to the interstate Agreements on cooperation in the field of tourism, great responsibility for its implementation was assigned to the activities of cultural and tourist institutions. In particular, on the basis of the agreements reached, the "Uzbektourism" National Company, together with the Ministry of Tourism and Sports of the Republic of Kazakhstan, began to develop an action plan and implement a joint tourism business. It included several areas of tourism events, each of which was distinguished by the originality and originality of routes. So, for example, the first of the directions provided for the wide familiarization of citizens of both states with achievements in the field of economics, social development, culture, nature, interesting historical monuments, as well as with the traditions of the peoples of both countries. The second direction provided for the organization of joint tourist routes: along the Great Silk Road. The third area is the organization of air routes in the capitals of the republics of Central Asia. The fourth direction is inter-republican bus routes in the cities of Uzbekistan and Kazakhstan. And finally, the fifth direction mutual tourist and excursion service - routes on tourist trains [5, p.29].

In addition, within the framework of the above Agreements, Uzbektourism National Company on the one hand, the Ministry of Tourism and Sports of the Republic of Kazakhstan on the other hand, pay great attention to the mutual participation of their representatives at events organized both by the World Tourism Organizations on a global scale and in the framework of bilateral events held in the field of tourism. This creates a favorable environment for establishing close contacts between travel companies and companies from different countries hold an exchange of views on pressing issues in the field of the tourism industry, outline long-term plans for mutual cooperation in order to further increase the flow of tourist exchange. 


\section{SJIF Impact Factor: 6.260| ISI I.F.Value:1.241| Journal DOI: 10.36713/epra2016 ISSN: 2455-7838(Online) EPRA International Journal of Research and Development (IJRD)}

So, for example, in March 1996, the International Tourism Fair (ITB) - 96 was held in Berlin (Germany). More than 170 countries of the world participated in its work, among which Uzbekistan, Kazakhstan and Kyrgyzstan also presented their tourism potential $[6, \mathrm{p} .1]$.

The delegation of Uzbekistan to ITB-96 was represented by 8 independent and regional divisions of the Uzbektourism National Company, Uzbekistan Havo Yullari NAC and one private travel company. The main tasks entrusted to the delegation were to promote the achievements of independent Uzbekistan, its domestic and foreign policy, unique opportunities in the field of tourism and, of course, attracting a large number of foreign tourists to the republic [6, p.3].

It is important to note that within the framework of ITB - 96, the Bazaar was held on the Silk Road - Questions and Problems. Representatives of the Silk Road countries, in particular Uzbekistan, Kazakhstan and Kyrgyzstan, participated in their stands and materials. This event provided an opportunity to discuss the problems arising from the organization of combined tours of the Silk Road. Much attention was paid to the continuation of previously begun joint work with the World Tourism Organization to promote a project related to the revival of the tourist route along the Great Silk Road, which directly runs through the territory of Central Asian countries [6, p.3].

Another important event in bringing together the tourism potentials of Uzbekistan and Kazakhstan was their participation in the 30th Meeting of the WTO Commission on Europe, which was held in Germany in June 1996. Taking part in the seminarmeeting of the delegation of Central Asian countries, they saw as the main goal the need for propaganda for the development of the Great Silk Road project and attracting a large influx of tourists to it. In this regard, the WTO Deputy Secretary General Francesco Frangialli noted that: "The annual International Tourism Fair promotes the joint efforts of the countries located on the Silk Road, in order to more actively develop cooperation among themselves and attract foreign tourists from Europe and America to these countries" [7, p.1-3].

Therefore, the same meetings, where a wide range of issues of international tourism exchange were discussed, were repeatedly held in the countries of Central Asia themselves. So, for example, in October 2004, the $10^{\text {th }}$ International Tourism Fair was held in Tashkent. In its work, along with companies from many countries of the world, representatives of travel agencies of Kazakhstan took part. During the fair, each participating country presented an exhibition reflecting its tourism potential. This carries a lot of information, opening up new aspects for cooperation. This is evidenced by the numerous agreements reached between tourism companies and firms in Uzbekistan and Kazakhstan [8, p.4].

The same event on a global scale, in April 2005, was held in the Republic of Kazakhstan. The $5^{\text {th }}$ Anniversary Kazakhstan International Tourism Fair "Tourism and Travel" KITF-2005 was held here in Almaty, where, along with delegates from many countries of the world, representatives from both the Republic of Uzbekistan and the Republic of Kyrgyzstan also took part. This meeting allowed us to further expand the boundaries of interaction between tourism companies and firms of the Central Asian republics. So, for example, such tourist companies of Uzbekistan as Uzintur, Asiaintourbusiness, actively cooperate with tourist companies of Kazakhstan in the field of tourist exchange and organization of combined tours along the Great Silk Road. Among the large Kazakh tourism organizations that are actively involved in the exchange of tourists can be called such as "Nomad Travel", "Makus Silk Road Adventures" and others [9, p.5-6].

In order to accelerate the development of tourism in Uzbekistan, by the Decree of the President of the Republic of Uzbekistan dated December 2, 2016, an authorized state body, the State Committee for Tourism Development, was formed to more effectively promote the national tourism potential in the domestic and foreign markets. Today in Uzbekistan there are 795 Travel companies and as of 2018 the tourist flow is -5 million tourists [10].

In June 2017, in Astana, the National Chamber of Kazakhstan "Atameken" and the Association of Private Tourism Organizations of Uzbekistan entered into an agreement on cooperation in the field of tourism. The National Tourism Product Promotion Center under the State Committee for Tourism of Uzbekistan and the Kazakh Tourism National Company, as well as the Ontustik Tourism Center tourist information center, signed memorandums of cooperation [11].

\section{CONCLUSION}

The opening between the countries of rail and road communications positively contributes to the growth of tourist flow to both countries, which we can observe today. The high-speed passenger train Almaty-Tashkent, Tashkent-Almaty, additional Astana-Tashkent flights are indicators of cooperation in this area, the visa-free regime established by the two republics contributes to such positive dynamics. The close and coordinated interaction between tourism companies and firms of the republics plays an important role in the regular exchange of tourists. 
In conditions of independence, the mutual interest of the peoples of Uzbekistan and Kazakhstan to the cultural and historical monuments of antiquity, as well as modern sights and achievements of socioeconomic transformations, does not weaken is growing. This helps to strengthen the bonds of friendship and cooperation between the peoples of our republics. Moreover, this form of cultural and spiritual interaction between peoples serves as one of the most stable forms of public diplomacy in strengthening interstate cooperation.

\section{REFERENCES}

1. The current archive of the National Company "Uzbektourism". (Further - CA NC

"Uzbektourism”). Report folder for 1993.

2. Promoting Regional Tourism Cooperation within CAREC 2030 Preliminary Study, Asian Development Bank, March 2019. https://www.adb.org/sites/

3. CA NC "Uzbektourism" Folder Kazakhstan. 1994

4. CA NC "Uzbektourism" Folder Kazakhstan. 1997

5. CA NC "Uzbektourism" Folder Kazakhstan. 2000

6. CA NC "Uzbektourism". Report folder on the International Tourism Fair (ITB) - 96.

7. CA NK “Uzbektourism". Report folder on the 1996 WTO Commission Meeting in Europe.

8. CA NC "Uzbektourism". Report folder for international events.

9. CA NK "Uzbektourism" Folder Kazakhstan. 2005

10. https://uzbektourism.uz

11. https://uz.sputniknews.ru/tourism 